\title{
Peran Kepemimpinan Guru Sekolah Minggu Bagi Pertumbuhan Spiritualitas Generasi Z Pada Era Disrupsi
}

\author{
Ricky Mallisa' \\ Institut Agama Kristen Negeri Toraja \\ rickymallisa@gmail.com
}

\begin{abstract}
The purposes of this research is to analyze the leadership role of Sunday school teachers for generation $z$ in the era of disruption. Disruption is a change in the human life system caused by the development of technological science. As a result, most human activities in the 21st century are assisted by a modern. In addition, the era of disruption was marked by the ease of access. This is an opportunity to do various activities quickly. The presence of opportunities for quick access also has an impact on the lives of Generation Z. But it makes it possible for easy access to pornographic sites that would adversely affect the $Z$ generation and its spiritual growth. Related to that, the leadership role of the Sunday school teacher must guide the z generation in a better direction. So that, the research method used in this research is descriptive qualitative. The approach used in literature research. After that, it is described in a description. Regarding the leadership role of Sunday school teachers for generation $z$ in the era of disruption, the findings in this study are (1) Building spirituality for generation z. (2) Educational approach. That is meant is the role of school teacher leadership to provide education oriented to the growth of Christ's character. (3) The principle of benefits approach that must be utilized for ministry, discipleship, and in the mission of the church. (4) Schoolteacher leadership is characterized by a role model for generation Z. In providing exemplary to $z$ generation is grow in faith in the midst namely digital sophistication in the Era of Disruption.
\end{abstract}

Keywords: Disruptive, spirituality, Leadership, Z Generation.

Abstrak: Tujuan penelitian adalah untuk mengkaji peran kepemimpinan guru sekolah minggu terhadap generasi $\mathrm{Z}$ di era disrupsi. Disrupsi adalah perubahan sistem kehidupan manusia yang disebabkan oleh berkembangnya ilmu teknologi. Akibatnya sebagian besar aktivitas manusia di abad ke-21 ini dibantu oleh kehadiran digital yang modern. Selain itu, Era Disrupsi ditandai dengan adanya kemudahan dalam mengakses. Hadirnya peluang akses yang cepat juga berdampak bagi kehidupan generasi Z. Namun memungkinkan peluang akan mudahnya membuka situs pornografi yang berdampak buruk bagi generasi $\mathrm{Z}$ dan pertumbuhan spiritualitasnya. Terkait itu, peran kepemimpinan guru sekolah minggu harus membimbing generasi $\mathrm{Z}$ ke arah yang lebih baik. Maka metode penelitian yang digunakan adalah kualitatif deskriptif. Pendekatan yang digunakan adalah literature research. Setelah itu diuraikan secara deskripsi. Terkait peran kepemimpinan guru sekolah minggu bagi generasi Z di era disrupsi, maka temuan-temuan dalam penelitian ini adalah (1) Membangun spiritualitas bagi generasi Z. (2) Melakukan pendekatan secara edukatif. Artinya peranan kepemimpinan guru sekolah memberikan pendidikan yang berorientasi pada pertumbuhan karakter Kristus. (3) Pendekatan asas manfaat yang harus dimanfaatkan untuk pelayanan, pemuridan, dan dalam misi gereja. (4) Kepemimpinan guru sekolah minggu ditandai dengan role 
model. Artinya memberikan keteladanan bagi generasi Z untuk semakin bertumbuh dalam iman di tengah kecanggihan digital di Era Disrupsi.

Kata kunci: Disrupsi, Spiritualitas, kepemimpinan, Generasi Z

\begin{tabular}{llll}
\hline Article History : & Received: 16-11-2020 & Revised: 27-12-2020 & Accepted: 28-12-2020
\end{tabular}

\section{Pendahuluan}

Era Disrupsi dikenal dengan perubahan memasuki era digital. Perubahan yang dimaksudkan ialah perubahan dimana manusia belum menggunakan gadget dengan mahir, sekarang gadget telah menjadi bagian dari kehidupan. Seorang ahli disrupsi, Terence Mauri mengatakan bahwa disrupsi berarti pergeseran atau pergantian dari cara melakukan sesuatu yang dulu ke cara yang berlaku saat ini. Artinya ialah disrupsi telah mempengaruhi seluruh aspek kehidupan manusia. ${ }^{1}$ Hadirnya era digital akan sangat berdampak besar bagi kehidupan manusia. Tujuan penulisan ialah mencari tahu dampak negative dan positif dari perubahan sistem kehidupan yakni era disrupsi sehingga diketahui hal yang menjadi pusat permasalahan dalam kajian ini sehingga memungkinkan terjadinya penanggulangan. Dampak positifnya terletak pada kehadiran teknologi digital yang memudahkan aktivitas manusia dengan cepat. Bahkan dalam dunia bisnis, ekonomi dan pemerintahan menjadi tertata baik dengan hadirnya era disrupsi. $^{2}$ Selain dampak positif, tentu memiliki dampak negatif. Dampak negatif teknologi digital adalah mengarah kepada kendala metode bisnis dengan penyaing yang memanfaatkan teknologi digital dengan tidak sehat. Serta penggunaan gadget yang salah akan menimbulkan masalah baru khususnya warga gereja. Masalah yang muncul terkait gadget adalah penggunaan media sosial yang salah diantaranya; ujaran kebencian, hoaks, pornografi, dan lain-lain. Masalah tersebut bukan hanya terjadi pada warga gereja dewasa, tetapi juga dalam kehidupan anak-anak yang dikenal dengan istilah gererasi Z. Generasi Z adalah angkatan setelah generasi $\mathrm{Y}$ yang didefenisikan secara umum sebagai generasi yang lahir antara tahun 1998-2010. Generasi Z perlu menggunakan kecanggihan teknologi dengan baik agar spiritualitas dapat bertumbuh dengan baik pula. ${ }^{3}$ Dalam menyikapi fenomena tersebut maka pentingnya penyelesaian penulisan kajian ini agar titik masalah kajian ini dapat diselesaikan melalui peran kepemimpinan Gereja dalam hal ini tindakan para Pendeta, Penatua dan diaken serta pengurus OIG, khususnya guru sekolah minggu untuk memberikan pendampingan yang baik. Jika para pemimpin gereja tidak memahami perannya maka akan menimbulkan dampak yang tidak baik terhadap kehidupan Gereja (generasi Z) di masa sekarang dan masa yang akan datang.

\footnotetext{
1 Septiadhi, Dwinanda, Disrupsi. (Depok: Baraqa Publishing, 2019), 89.

${ }^{2}$ Ibid, 89-90.

${ }^{3}$ Femy Tandilintin Aussie, Remaja dan Media Sosial (Studi Analisis Dampak Media Sosial bagi Perilaku Remaja dalam kehidupan Sosial di Kecamatan Makale Kabupaten Tana Toraja): Jurnal STAKN Toraja, Vol 12019.
} 
Pemimpin gereja harus sadar bahwa generasi gereja tidak dapat dipisahkan dari era digital ini. Era digital ini ditandai dengan penggunaan gadget dalam lingkungan keluarga (lingkungan internal), dan dunia luar (lingkungan eksternal). ${ }^{4}$ Tidak bisa dipungkiri bahwa Era Disrupsi berhadapan dengan generasi Z. Inilah fenomena yang terjadi sekarang ini tanpa disadari secara perlahan akan mengubah karakter Generasi Z. Oleh sebab itu peran kepemimpinan guru sekolah minggu yang sesungguhnya harus hadir di tengah-tengah kehidupan mereka. Terkait itu, maka guru sekolah minggu harus menjalankan misi pelayanannya di tengah kehidupan era disrupsi saat ini. L. Harry Santoso seorang pelatih kepemimpinan dan komunikasi menegaskan bahwa kepemimpinan membicarakan persoalan sejarah peradaban manusia di masa depan dan bahwa kepemimpinan berkaitan dengan nasib manusia di masa depan. ${ }^{5}$ Ketimpangan yang terjadi saat ini membuat spiritualitas anak justru goyah, perbandingan dunia sebelum Era Disrupsi ialah dunia tanpa sentuhan teknologi digital (tradisional) dengan dunia yang dipengaruhi teknologi digital (modern) mulai ada sangat terlihat jelas perbedaannya bahwa saat dunia tradisional begitu sulit untuk menjangkau informasi secara global sedangkan dunia modern akses mendapatkan informasi sudah begitu mudah dan tanpa batas setelah masa di era disrupsi saat ini sehingga sikap yang paling tepat dalam menghadapi masalah ini adalah mencari tahu akan akar masalah yang ada sehingga hal itu yang harus diubah sehingga menghasilkan tujuan yang benar. ${ }^{6}$ Teknologi digital tidak bisa dihilangkan dari kehidupan manusia. Namun teknologi digital bisa diatur untuk tidak digunakan secara berlebihan agar tidak berdampak pada intelektual dan karakter anak, menurut para ahli keberhasilan suatu kepemimpinan ditentukan oleh kejelasan akan tujuan kepemimpinan yang seperti apa yang hendak di capai. Sehingga seorang pemimpin akan mampu mengarahkan, memimpin dan membawa Generasi Z menuju suatu tujuan yang lebih baik di masa depan. ${ }^{7}$

\section{Metode Penelitian}

Melihat masalah yang akan dikaji dalam penulisan ini maka metode penelitian yang digunakan adalah metode Kualitatif deskriptif. Penelitian Kualitatif Deskriptif merupakan penelitian yang dilakukan dengan cara menganalisis dan memaparkan secara deskriptif tentang peran kepemimpinan guru sekolah minggu bagi generasi $\mathrm{Z}$ di tengah tantangan era disrupsi. Keunggulan penelitian kualitatif deskriptif ialah memiliki kepekaan melihat gejala-gejala yang ada pada obyek penelitian, mampu menghasilkan temuan pengetahuan atau ilmu baru bahkan mengkonstruksi fenomena, serta mampu

\footnotetext{
${ }^{4}$ Midayana, Evia Darmawani, Dessi Andriani, Dampak Penggunaan Gadget Pada Anak Usia Dini (Studi Kasus di TK Elekrina Kertapati Palembang): Jurnal PAUD, Vol 22019.

5Pr. Y. Gunawan, Kepemimpinan Kristiani: Melayani Sepenuh Hati (Yogyakarta: Kanisius, 2014), 5.

${ }^{6}$ Ibid, 6.

7 Ibid, 7-8.
} 
menguji kredibilitas, dependabilitas, konfirmabilitas, dan transferabilitas hasil penelitian. Dengan menggunakan jenis penelitian ini akan memberikan kejelasan mengenai permasalahan yang terjadi dalam era disrupsi saat ini, yakni bagaimana sesungguhnya peran kepemimpinan guru sekolah minggu dalam menghadapi sistem kehidupan dalam perubahan di era disrupsi ini. ${ }^{8}$ Tujuan penulisan judul ini yang dimaksudkan untuk memecahkan masalah tersebut dapat diselesaikan dengan metode deskriptif dan oleh karena itu sangat penting usaha-usaha yang dilakukan seperti mengenali, melihat, menganalisis untuk memahami setiap masalah terkait penulisan judul ini untuk mendapatkan hasil dari pemecahan masalah tersebut.

\section{Hasil dan Pembahasan}

\section{Kajian Era Disrupsi}

Istilah "Disrupsi" muncul ketika seorang guru besar Harvard Business School, Clayton M. Christensen menerbitkan sebuah buku yang berjudul "The Innovator Dilemma" pada tahun 1997.9 Buku tersebut berisi penguraian atau penjelasan tentang persaingan dalam dunia bisnis kala itu serta buku tersebut berfokus pada inovasi, keingintahuan Christensen kala itu dengan melihat sebuah fenomena yang menurutnya menarik bagaimana tidak fenomena tersebut merujuk pada keadaan dimana suatu perusahaan besar dengan pemimpin yang hebat dikalahkan oleh suatu perusahan kecil dengan pemimpin dengan skill yang terbatas. Akhirnya hasil penelitian dari buku Christensen ini menguak fakta tentang adanya pengaruh disrupsi yakni suatu perubahan besar terhadap dunia bisnis. Disrupsi atau perubahan mengacu pada dunia bisnis dan komunikasi. Jurnal Komunikasi Indonesia (JKI) Vol 72018 mengulas terjadinya disrupsi dalam dunia media online yang mengambil langkah pasar bawah (harga murah) sehingga media konvensional tersaingi. Hal inilah yang disebut sebagai titik awal dari proses disrupsi. Oleh karena itu para ahli juga mengaitkannya dengan perubahan yang merujuk pada dunia digital seperti seorang ahli yang bernama Paul Paetz yang berpendapat bahwa Digital juga merupakan faktor pengaruh terbesar dari percepatan proses Disrupsi. ${ }^{10}$

Disrupsi digital sebenarnya membawa konsekuensi pada cara dan pendekatan yang baru. Febby Amelia Trisakti dan Hifni Alifahmi membahas mengenai penggunaan Storytelling dengan tujuan untuk memperkuat brand yang berkaitan pada pemasaran atau penawaran digital. ${ }^{11}$ Francis Fukuyama menerbitkan buku The Great Disruption Human Nature And The Reconstitution Of Social Order pada tahun 1999, yang berisi pandangan Fukuyama terhadap perubahan masyarakat di akhir abad ke-20. Hal ini jelas

\footnotetext{
${ }^{8}$ Mardalis, Metode Penelitian: Suatu Pendekatan Proposal (Jakarta: Bumi Aksara, 2010), 24. 2018).

9 Eriyanto, Disrupsi. Jurnal Departemen Ilmu Komunikasi, FISIP Universitas Indonesia, (Depok

${ }^{10}$ Ibid

11 Ibid
} 
berbeda dengan pandangan Christensen. ${ }^{12}$ Berdasarkan karya Fukuyama yang membahas Teknologi dan Informasi yang mulai mempengaruhi pola-pola relasi komunikasi membuat Marshall McLuhan mengistilahkan dunia selebar daun kelor. Artinya dunia sudah begitu sempit seakan dalam genggaman karena kecanggihan digital memberi dampak baik terhadap kekacauan sosial maupun perubahan fundamental pada dunia industry.

Disrupsi menurut Fukuyama berarti gangguan atau kekacauan. Sedangkan Christensen melihat disrupsi dalam hubungannya sebagai peluang inovasi. Prof. Sudaryono mengungkapkan bahwa jika disrupsi diartikan secara majemuk dalam konteks Indonesia maka menunjuk pada gangguan terhadap ilmu pengetahuan namun juga akan menjadi peluang bagi pengembangan Pendidikan tinggi. ${ }^{13}$ Jadi apakah Era Disrupsi hanya berbicara dalam konteks dunia bisnis saja? Rhenald Kasali menegaskan bahwa Disrupsi juga berbicara dalam bidang kehidupan manusia baik pemerintah, dunia hiburan dan dunia sosial. ${ }^{14}$ Sehingga disrupsi akan mengubah dinamika kehidupan secara berkelanjutan dengan sangat cepat bahkan hal tersebut berdampak pada kegiatan sehari-hari. ${ }^{15}$ Oleh karena itu sangat penting bagi manusia yang masih merasakan era disrupsi dimana dipacu oleh banjirnya informasi, perubahan yang disertai akselerasi agar menghambat terjadinya ketinggalan zaman. ${ }^{16}$ Menurut kamus besar Bahasa Indonesia disrupsi diartikan sebagai "tercabut dari akarnya", artinya bahwa disrupsi adalah terjadinya suatu perubahan yang mendasar yakni perubahan teknologi.

Digitalisasi merupakan akibat dari perubahan teknologi sebab hampir dari setiap aspek kehidupan manusia turut mengalami perubahan termasuk dalam tatanan usaha yang dikerjakan manusia. ${ }^{17}$ Era disrupsi bisa terjadi karena adanya perkembangan teknologi komunikasi yang keberadaannya telah menghapus batas-batas geografis dan menghasilkan inovasi terbaru yang mengubah cara hidup dan mengganti sistem yang ada. ${ }^{18}$ Cragun dan Sweetman pada tahun 2016 menyatakan ada lima pemicu gelombang disrupsi yang terjadi sejak tahun 1980 hingga 2015 yakni: Teknologi, kepemimpinan-

\footnotetext{
${ }^{12}$ Ohoitimur Johanis, Disrupsi: Tantangan Bagi Perkembangan Ilmu Pengetahuan dan Peluang bagi Lembaga Pendidikan Tinggi. Jurnal Unika Atma Jaya (Jakarta 2018): 144.

13 Ibid, 144.

14 Ibid, 146-149.

15 Rahayu Imam Susanto, Era Disrupsi: Peluang Dan Tantangan Pendidikan Tinggi Indonesia (Jakarta: Akademi Ilmu Pengetahuan Indonesia, 2017), 115.

16 Tanuadjaja, Rahmiati, Spiritualitas Kristen dan Apologetika Kristen (Malang: Literatur Saat, 2018, 5-8.

${ }^{17}$ Ika, Era Disrupsi Dan Implikasinya Bagi Reposisi Makna Dan Praktek Pendidikan: Jurnal Media Komunikasi Pendidikan Pancasila Dan Kewarganegaraan Vol 1 2019, 56.

${ }^{18}$ Ibid, 57.
} 
manajemen-SDM, peristiwa ekonomi daya saing global, geopolitik (ketegangan antar wilayah). ${ }^{19}$

\section{Dampak Era Disrupsi bagi Generasi Z}

Dampak era disrupsi terhadap Generasi Z pada dasarnya berdampak positif. Hal tersebut disebabkan karena kehadiran teknologi digital yang menunjang aktivitas dan memicuh penyelesaian masalah dalam kehidupan Generasi Z tersebut. ${ }^{20}$ Khususnya aktivitas di rumah, di sekolah yang telah menggunakan perubahan sistem kehidupan saat ini. Contohnya penggunaan handphone, dan beberapa animasi teknologi yang menunjang akan penyelesaian tugas, belajar, bermain, dan berkarya. Perkembangan teknologi saat ini mampu memberikan dampak pertumbuhan spiritualitas Generasi Z. sehingga sangat relevan ketika kemajuan teknologi digunakan untuk pelayanan yang dinamis dan peka terhadap perkembangan zaman. Tujuan akhirnya adalah memberikan dampak kesejahteraan. Dampak lain yang dihasilkan oleh perkembangan teknologi terhadap kehidupan Generasi Z adalah peningkatan kreativitas untuk menyuarakan kebenaran Firman Tuhan seperti yang tercatat dalam Matius 28:19-20 "Karena itu pergila, jadikanlah semua bangsa murid-Ku dan baptislah mereka dalam nama Bapa dan Anak dan Roh Kudus, dan ajarlah mereka melakukan segala sesuatu yang telah kuperintahkan kepadamu. Dan ketahuilah, Aku menyertai kamu senantiasa sampai kepada akhir zaman."

Kendala saat ini adalah keterbatasan keluarga dalam mengedukasi Generasi Z untuk memanfaatkan digital sebagai alat dan sarana dalam membangun intelektualitas dan spiritualitas generasi Z. Dampak positifnya ialah Generasi Z menggunakan teknologi digital agar pembelajaran di rumah, di sekolah dan di Gereja dapat berjalan bersama secara teratur. ${ }^{21}$ Ketika kecenderungan dari Generasi $\mathrm{Z}$ menggunakan alat digital hanya untuk bermain game online, menonton Youtube, dan bahkan membuka situs-situs pornografi. Akibatnya, menghambat proses pola pikir, hubungan atau interaksi sosial, dan bahkan mengubah perilaku anak terhadap orang tua dan orang lain yang ada disekitarnya.

Anak yang menghabiskan waktunya dengan bermain gadget akan membentuk suatu kepribadian yang lebih emosional, pemberontak karena merasa terganggu, kehilangan minat untuk melakukan aktivitas lain seperti belajar, membentuk karakter penyendiri, cenderung egois dan mudah marah, terlatih berbohong. ${ }^{22}$ Bentuk kelemahan lain karena penggunaan gadget pada perkembangan Generasi Z yakni: sering lupa waktu (waktu terbuang sia-sia), mengganggu perkembangan otak, menggganggu kesehatan

\footnotetext{
${ }^{19}$ Ibid, 56-58.

${ }^{20}$ Siswanto Igrea, Digital Multimedia: Teknologi Penunjang Pembelajaran PAK Dan Sekolah Minggu (Tangerang: Matana Publishing, 2016), 2.

21 Ibid, 1-3.

${ }^{22}$ Femy Tandilintin Aussie, Anak Dan Kecanduan Digital (kids and digital addicts): Jurnal STAKN Toraja, Vol 12018.
} 
mata, ketidakpekaan terhadap lingkungan sekitar, menjadi seorang yang introvert dan menganggap bahwa gandget adalah segala-galanya dalam kehidupan kesehariannya. ${ }^{23}$ Dari sekian dampak yang telah terpapar di atas maka semuanya itu merupakan suatu tantangan sendiri bagi kehidupan dalam keluarga, sekolah secara formal, dan bahkan Gereja (sekolah minggu) yang sebenarnya merupakan suatu pusat dalam pelayanan akan pemberitaan Firman Tuhan, Amsal 1:5 "baiklah orang bijak mendengar dan menambah ilmu dan baiklah orang yang berpengertian memperoleh bahan pertimbangan." Secara psikologi dampak dari Era Disrupsi ialah timbulnya pemikiran Egosentris. Artinya pemikiran yang berpusat pada kepentingan diri sendiri.

Egosentrisme adalah buah ekstrem dari egoism psikologi yang cenderung menguntungkan diri sendiri sehingga nilai manusia sebagai makhluk sosial terabaikan. ${ }^{24}$ Berpikir relativis, cara berpikir relativis itu adalah penolakan terhadap suatu kebenaran yang universal atau secara sederhananya, pandangan ini menyatakan bahwa tidak ada sebuah standar yang sama berlaku untuk setiap orang namun kemudian hanya bersifat relative. ${ }^{25}$ Menurut Erich Schmidt dan Jared Cohen mengatakan bahwa sisi negatif dari pada kehadiran digital di era disrupsi yakni komunikasi yang terjalin secara fisik (antarpribadi, antar-masyrakat) kini telah tergantikan oleh dunia maya. Sebagai contoh: di era ini kemahiran generasi $\mathrm{Z}$ dalam pengaplikasian game online mengakibatkan mereka kecanduan dalam menggunakannya sehingga berdampak buruk terhadap sisi sosialitasnya. Mengapa demikian? Dengan adanya kecanduan digital, generasi Z tidak lagi mengetahui tata krama yang baik, serta membatasi diri berinteraksi dengan orang lain. Bahkan menjadikan kecanggihan digital sebagai alat penyebar hoax. ${ }^{26}$

\section{Pengertian Kepemimpinan}

Kepemimpinan menurut George Terry adalah aktivitas memengaruhi orang lain secara sukarela berjuang mencapai tujuan-tujuan kelompok. ${ }^{27}$ Menurut ilmu manajemen adalah sebuah keahlian berorganisasi yang terdiri dari ilmu manajemen dan leadership skill. Artinya kepemimpinan sebagai keterampilan untuk mengatur suatu organisasi. Menurut ilmu kepemimpinan itu sendiri adalah proses yang dilakukan melalui cara-cara tertentu untuk memberikan dampak kepada sekelompok orang untuk terpengaruh akan sebuah tujuan tertentu agar bisa kemudian bersama-sama mewujudkan itu dalam suatu organisasi.

\footnotetext{
${ }^{23} \mathrm{Ibid}$

${ }^{24}$ Sihotang, Kasdim, Berpikir Kristis kecakapan Hidup Di Era Dsirupsi (Yogyakarta: Kanisius, 2019), 20-21.

${ }^{25}$ Ibid, 22-24

${ }^{26}$ Ibid, 20-29.

${ }^{27}$ Nurhayati, Tati, Hubungan Kepemimpinan Transformasional Dan Motivasi Kerja: Jurnal Edueksos, Vol 12012.
} 
Kepemimpinan selalu berkaitan dalam kerjasama yang baik dengan kelompok, dimana seorang pemimpin juga mampu memulai suatu usaha terhadap kelompok. ${ }^{28}$ Faktor yang menjadi pengaruh terhadap kepemimpinan adalah berasal dari diri sendiri, mengapa demikian? Karena menyangkut bagaimana cara pandang setiap individu, dan bagaimana situasi kepemimpinan dilaksanakan. Menurut Prof. John Kotter kepemimpinan itu menentukan arah. Kepemimpinan bertujuan untuk melibatkan setiap orang bahkan kepemimpinan juga bertujuan memotivasi untuk mencapai kesejahteraan bersama. Menurut Chris Lowney kepemimpinan itu memahami kekuatan dan kelemahan dalam diri dan kelompok.

Kepemimpinan yang berinovasi dan beradaptasi terhadap keyakinan diri merangkul perubahan-perubahan dalam dunia yang terus berubah seiring berjalannya waktu. Kepemimpinan juga harus bersikap positif dan penuh dengan cinta kasih. Bahkan kepemimpinan yang memiliki prinsip kesadaran diri. Jadi kepemimpinan di abad ke-21 adalah kepemimpinan yang mengarah kepada kepemimpinan transformatif. Kepemimpinan transformatif adalah ciri yang melekat pada sebuah gaya kepemimpinan yang mempengaruhi anggota kelompok untuk mencapai tujuan. Kepemimpinan ini merupakan corak dari kepemimpinan Kristiani karena Yesus juga turut mengajarkan jenis kepemimpinan yang transformatif. Senada yang diungkapkan Santo Ignatius bahwa kepemimpinan yang transformatif sejajar dengan kepemimpinan Kristus dalam karya penyelamatan-Nya. ${ }^{29}$

\section{Pengertian Generasi Z}

Generasi $\mathrm{Z}$ atau iGeneration atau generasi net biasa juga disebut sebagai generasi internet. Generasi Z adalah Angkatan yang lahir paska tahun 2001 dan merupakan bagian yang besar dari keseluruhan populasi manusia. Kecenderungan generasi $\mathrm{Z}$ ialah suka menabung, durasi online cukup lama serta generasi ini begitu mencolok aktivitasnya. Artinya kemampuan mereka atau kemahiran mereka menggunakan atau mengaplikasikan alat digital seperti bermain game dan menonton youtube hal tersebut sudah terlatih sejak dari balita. Sejak kecil sudah diperkenalkan handphone sehingga kemahirannya tidak dapat diragukan lagi ketika dalam usia kanak-kanak mereka telah menggunakan media sosial dan berbagai fitur lainnya yang tersedia di Era Disrupsi ini. ${ }^{30}$

Generasi $\mathrm{Z}$ adalah generasi digital yang mahir ataupun gandrung dalam penggunaan teknologi informasi untuk kepentingan hidupnya, bahkan generasi $\mathrm{Z}$ ini begitu hebat dalam berkomunikasi dan berinteraksi dengan semua kalangan sehingga memicu perubahan kepribadiannya, namun dalam mengepresikan apa yang dirasakan generasi ini cenderung toleran terhadap perbedaan kultur dan memiliki kepedulian

${ }^{28}$ Keating, Charles J, Kepemiminan: Teori dan Pengembangannya (Yogyakarta: Kanisus, 1986), 9-

${ }^{29}$ Ibid, 4-5, 26-27.

${ }^{30}$ Wijoyo Hadion, dkk. Generasi Z dan Revolusi Industri 4.0. (Purwokerto: Pena Persada, 2020), 1. 
terhadap lingkungan. ${ }^{31}$ Generasi $\mathrm{Z}$ adalah generasi yang multitasking, terlihat dari kebiasaan melakukan berbagai aktivitas dalam satu waktu. Generasi Z juga mampu melakukan beberapa aktivitas dengan cepat. ${ }^{32}$

Forbes Magazine melakukan riset kepada 49 anak di Amerika Utara dan Selatan, Afrika, Eropa, Asia dan Timur Tengah. Hasil riset tersebut menyatakan bahwa generasi Z adalah generasi yang berada dalam lingkungan yang tidak pasti dan kompleks. Ciri lain dari Generasi $\mathrm{Z}$ adalah mereka menyukai kebebasan dan tidak menyukai otoritas dan bahkan generasi $\mathrm{Z}$ adalah generasi yang tidak mengadakan pengelompokanpengelompokan berdasarkan usia dan mereka juga tidak memilih ingin bergaul hanya dengan laki-laki atau perempuan namun generasi $\mathrm{Z}$ ini lebih mementingkan kecocokan atau sejalan tidaknya pemikiran mereka. ${ }^{33}$ Dalam hal penataan kehidupan dan kepribadian generasi $\mathrm{Z}$ ditengah era disrupsi dalam hubungannya dengan Pendidikan untuk menanamkan nilai yang baik sejalan dengan penggunaan teknologi agar kepribadian generasi $\mathrm{Z}$ tidak mandeg.

\section{Peran Kepemimpinan Guru Sekolah Minggu Terhadap Pertumbuhan Spiritualitas Generasi Z dalam Era Disrupsi}

Guru Sekolah Minggu adalah wakil Allah di dalam menjalankan misi Kerajaan Allah bagi kehidupan generasi $\mathrm{Z}$, guru memang pada dasarnya memberikan pengajaran kepada setiap anak yang dihadapi. ${ }^{34}$ Menurut Setiawani guru sekolah minggu adalah seorang yang mementingkan pembinaan hidup, setia dan bertanggung jawab, dapat menjadi teladan serta terus memperlengkapi diri. ${ }^{35}$ Hendricks mengatakan bahwa menjadi guru berarti menjadi seorang pengajar karena guru adalah pembelajar murid diantara murid itu sendiri, sehingga seorang guru seharusnya terus berkembang dan mengalami perubahan metode ke arah yang lebih baik lagi (2 Petrus 3:18). Secara ideal bahwa tujuan pengajaran yang diberikan oleh seorang guru agar setiap generasi Z yang adalah siswa atau pelajar yang harus memiliki harapan serta cita-cita di masa yang akan datang. Dalam kitab Kolose 3:17;

"dalam segala sesuatu yang kamu lakukan dengan perkataan atau perbuatan lakukanlah semuanya itu dalam nama Tuhan Yesus, sambil mengucap syukur oleh Dia kepada Allah, Bapa kita."36

Ayat ini menekankan bahwa seorang guru sekolah minggu harus memiliki prinsip dan tanggung jawab untuk mengemban suatu tugas pelayanan sehingga menghasilkan visi

\footnotetext{
${ }^{31} \mathrm{Ibid}, 28$.

32 Ibid, 27.

33 Ibid, 60.

${ }^{34}$ Simanjuntak Julianto, dkk. Merekayasa Lingkungan Anak (Bandung: Kalam Hidup, 2014), 56

${ }^{35}$ Uli Nadapdap Marta, Pengaruh Profesionalisme Guru Sekolah Minggu Terhadap Pemahaman Materi Yang Diajarkan Pada Anak Usia 9-12 (Kelas Besar) Tahun Di GBI Taman: Jurnal Pendidikan Agama Kristen Regula Fidei, Vol 1 No 22016.

36 Ibid, 58.
} 
yang jelas yakni bahwa pekerjaan yang dilakukan adalah anugerah Tuhan ketika mendasarkan visi hidup terhadap keterpanggilan dalam pekerjaan Tuhan. Guru juga memiliki peran sebagai orang tua yang harus menyukai dan menyenangi anak (generasi Z). Oleh sebab itulah sangat penting untuk membangun rasa suka dan senang terhadap anak. Di lain sisi peran seorang guru harus memiliki kepribadian yang dapat diteladani oleh Generasi Z. Menurut psikologi perkembangan para generasi Z pada usia 3-7 tahun adalah para generasi yang suka meniru sehingga cenderung mengidolakan seseorang yang membuatnya mengikuti apa saja yang dilakukan sang idola.

Menurut Ny. Lieke A. Simanjuntak seorang tokoh Pendidikan Agama Kristen Indonesia mengatakan bahwa ada baiknya ketika kelompok sekolah minggu diajar dan di dampingi oleh para oma atau opa karena pengalaman yang matang sehingga dapat dijamin untuk tidak menirukan hal yang tidak baik bagi para generasi Z. Bertolak dari perihal ini maka guru selayaknya memiliki kompetensi yang bisa dikembangkan untuk pengajaran yang lebih baik lagi kepada generasi Z sebab generasi Z saat ini memiliki tiga (3) model belajar yang efisien digunakan yakni: pembelajaran secara visual, kinestik, dan auditori.

Adapun nilai-nilai yang penting ditanamkan kepada generasi $\mathrm{Z}$ saat ini ialah: penanaman nilai iman Kristen yang berorientasi pada hubungan manusia dengan Allah, penanaman moral dan karakter yang benar dan yang terakhir ialah penanaman etika dan perilaku yang baik dalam masyarakat. ${ }^{37}$ Tantangan akan peran kepemimpinan seorang guru sekolah minggu yang paling besar ialah memiliki kecakapan untuk mengarahkan dan membimbing generasi $\mathrm{Z}$ menjadi generasi yang justru memanfaatkan kecanggihan digital sebagai sarana kemudahan memperoleh informasi yang edukatif serta menanamkan nilai kristiani sehingga dari penerapan peran kepemimpinan seorang guru melahirkan generasi-generasi yang paham akan penggunaan alat digital dengan positif. ${ }^{38}$

Kepemimpinan guru sekolah minggu di Era Disrupsi dituntut untuk memberikan gagasan yang kreatif dan memiliki nilai intelektual bagi penerimanya. Kepemimpinan dibawah tuntunan Roh Kudus akan memberikan solusi atas setiap permasalahan yang beragam dalam penanganan karakter generasi Z. sehingga kepemimpinan guru sekolah minggu hendaknya berdasarkan pimpinan Roh yang akan menuntun, mengarahkan, membimbing, yang dilandasi dalam kesabaran, kesenangan hati berkarya, sukacita hingga menghasilkan damai sejahtera (Gal 5:22-23,25). ${ }^{39}$ Menempatkan diri pada posisi yang tepat adalah faktor yang mendukung generasi $\mathrm{Z}$ untuk tetap memiliki spiritual yang kokoh dalam Kristus ditengah perkembangan teknologi digital. Peran pemimpin dalam mendidik dan mengarahkan sangatlah penting agar generasi $\mathrm{Z}$ mampu memilah hal yang benar. Bahkan menjadi seorang teman atau sahabat generasi $\mathrm{Z}$ juga merupakan

\footnotetext{
37 Ibid, 59-63.

${ }^{38}$ Nelson Alan E. Spirituality \& Leadership (Bandung: Kalam Hidup, 2007), 23.

39 Ibid, 24-25.
} 
tindakan yang tepat untuk memperlihatkan keteladanan yang baik. Seperti memperlihatkan sikap untuk tidak menggunakan handphone saat ibadah serta tidak menggunakan handphone sebagai sumber kecanduan terhadap diri. ${ }^{40}$

Generasi Z lahir dan besar ditengah perkembangan teknologi digital yang sangat pesat. Oleh karena itu guru sekolah minggu perlu mempersiapkan diri dalam memanfaatkan teknologi digital dengan baik untuk menunjang pembinaan yang efektif. Seperti alat digital multimedia digunakan dalam penyampaian firman sebagai sarana yang menarik dan kreatif bagi generasi $\mathrm{Z}$ agar tidak bosan. Namun perubahan teknologi mengakibatkan generasi $\mathrm{Z}$ lebih menyukai berinteraksi dengan dunia maya dibandingkan dunia nyata. Fenomena seperti ini membuat peran guru juga harus mengikuti perkembangan zaman sehingga pendekatan baru dalam melayani generasi $\mathrm{Z}$ yakni membimbing generasi Z. Sehingga benar bahwa kepemimpinan guru sekolah minggu harus terus diperlengkapi dengan sebuah perkembangan diri yang berkualitas sehingga membawa anak kepada pertumbuhan Spiritualitas yang baik. ${ }^{41}$ Melihat perspektif Perjanjian Lama tentang peran kepemimpinan guru sekolah minggu yang aktif mengajar, seperti pengajaran Allah dalam kisah perjalanan Bangsa Israel ke tanah Kanaan berdasarkan yang berperan secara langsung dalam kehidupan Bangsa Israel.

\section{Membangun Spiritualitas Generasi Z}

Agar terjadi pertumbuhan spiritualitas bagi genarasi Z maka dibutuhkan peran kepemimpinan guru sekolah minggu yang mendidik, mengajar, mengarahkan serta menjadi teladan yang baik. Terkait kepemimpinan tersebut, maka tentu perlu melibatkan orang tua dan bahkan para pemimpin jemaat untuk membangun motivasi agar kepribadian generasi $\mathrm{Z}$ menjadi lebih baik. Artinya bahwa hal ini sejalan dengan tujuan untuk menuntun generasi $\mathrm{Z}$ agar memandang ibadah atau persekutuan sebagai sikap yang berkenan kepada Allah.

Pendekatan secara spirtualitas dengan gerakan cinta Alkitab untuk membangun kerohanian generasi Z harus dilakukan. Pendekatan spiritualitas yang dimaksud adalah metode pembelajaran firman Tuhan. Dasar Firman Tuhan adalah sebuah keharusan sebagai pedoman dan penuntun pada era ini tegas Daniel Ronda. ${ }^{42}$ Terkait itu, maka atas dasar Firman Tuhan akan menghantarkan generasi Z menuju perubahan sikap hidup untuk menjadi teladan bagi sesamanya. Orientasi membangun spirituallitas dapat dilakukan dengan menggunakan digital sebagai media komunikasi. ${ }^{43}$ Terkait pertumbuhan spiritualitas anak, maka secara praktis guru sekolah minggu dapat

40 Ibid. 53-55.

41 Siswanto Igrea, Digital Multimedia: Teknologi Penunjang Pembelajaran PAK Dan Sekolah Minggu (Tangerang: Matana Publishing, 2016), 3-7.

${ }^{42}$ Daniel Ronda, Orasi Ilmiah: Petan Pemimpin Kristen Memasuki Perubahan di Era Disrupsi Teknologi (Makassar: Jaffray, 2018), 12.

43 GP Harianto, Pendidikan Agama Kristen dalam Alkitab dan Dunia Pendidikan Masa Kini (Yogyakarta: Andi, 2012), 18-20, 30. 
melibatkan generasi Z dalam ritual keagamaan seperti berdoa atau bernyanyi, hal tersebut akan membangun sebuah kebiasaan generasi $\mathrm{Z}$ dalam pertumbuhan spiritualnya. ${ }^{44}$

\section{Pendekatan Edukatif}

Pendekatan edukatif adalah pendekatan yang bersifat mendidik, membimbing, dan mengarahkan pada suatu titik penyelesaian masalah. Terkait hadirnya era perubahan yang dikenal dengan era disrupsi, maka dubutuhkan pendekatan edukatif. ${ }^{45}$ Pendidikan adalah suatu usaha dengan sadar terencana dalam mewujudkan suasana proses belajar mengajar yang bertujuan agar peserta didik secara aktif dapat mengembangkan potensi dirinya untuk memiliki kekuatan spiritual keagamaan, pengendalian diri, kepribadian, kecerdasan, akhlak, demikian yang diungkapkan oleh Neolaka Amos. ${ }^{46}$ Terkait dengan pendekatan edukatif, pemimpin wajib membangun kepribadian berdasarkan etika Kristen dalam menggunakan media sosial dan mendorong komunitas Kristen (generasi gereja) bertanggung jawab untuk menghindari berbagai konten negatif, tidak menyebarkan hoaks, dan berbagai ujaran kebencian, tegas Daniel Ronda. ${ }^{47}$

Pendekatan edukatif adalah pendekatan yang bersifat mendidik. Oleh karena itu sikap guru sekolah minggu harus menampakkan tindakan dan perbuatan yang edukatif untuk memberikan manfaat terhadap kedisiplinan dan kepatuhan generasi $\mathrm{Z}$ terhadap sebuah aturan atau tatanan kehidupan yang baik. Sehingga pendekatan edukatif ini secara tidak langsung mengarah kepada tindakan mendidik generasi Z. ${ }^{48}$

\section{Pendekatan Asas Manfaat}

Pendekatan asas manfaat adalah sebuah pendekatan yang dilakukan untuk melihat manfaat atau kegunaan yang dirasakan dan yang sedang dialami. Hadirnya era disrupsi yang ditandai dengan adanya digital, maka tentu memiliki manfaat yang cukup signifikan. Daniel Ronda mengatakan dalam orasi ilmiahnya bahwa dunia digital memiliki pengaruh besar yang harus dimanfaatkan untk pelayanan, pemuridan, dan dalam misi gereja. ${ }^{49}$

Setiap warga gereja dapat menggunakan digital sebagai asas manfaat untuk megembangkan media dunia digital untuk mengembangkan diri baik dalam hal pengetahuan, pekerjaan, usaha, serta pelayanan. ${ }^{50}$ Terkait itu, maka sebagai guru

44 Fiah El Rifda, Mengembangkan Potensi Kecerdasan Spiritual Anak Usia Dini Implikasi Bimbingannya: Jurnal Bimbingan dan Konseling, IAIN Raden Intan (Lampung 2014).

45 Daniel Ronda, Orasi Ilmiah: Peran Pemimpin Kristen Memasuki Perubahan di Era Disrupsi Teknologi (Makassar: Jaffray, 2018), 12.

46 Neolaka Amos dan Neolaka A. Amelia Grace, Landasan Pendidikan: Dasar pengenalan diri Sendiri Menuju Perubahan Hidup (Depok: KENCANA,2017), 12.

47 Daniel Ronda, Orasi Ilmiah: Peran Pemimpin Kristen Memasuki Perubahan di Era Disrupsi Teknologi (Makassar: Jaffray, 2018), 12-13.

48 Hariyanto Eko dan Setya Mustafa Pinton, Pengajaran Remedial dalam Pendidikan Jasmani (Banjarmasin: Lambung Mangkurat University Press, 2020), 155.

49 Daniel Ronda, Orasi Ilmiah: Peran Pemimpin Kristen Memasuki Perubahan di Era Disrupsi Teknologi (Makassar: Jaffray, 2018), 14.

50 Ibid. 
sekolah minggu yang adalah seorang pemimpin bagi generasi $\mathrm{Z}$, harus membawa era digital yang ditandai dengan gadget kepada asas manfaat. ${ }^{51}$

\section{Pendekatan Keteladan}

Tantangan dalam era digital sangat besar. ${ }^{52}$ Gereja harus secara kreatif menyikapi hadirnya era perubahan ini. Era disrupsi yang ditandai dengan era digital sangat dekat dalam kehidupan gererasi Z. Para pemimpin harus mampu menunjukkan integritasnya bagi warga gereja khususnya generasi z. Oleh karena itu penting membangun komunitas warga netizen yang transparan dan menjaga komitmen kekudusan yang dimulai dalam keluarga dan komunitas gereja tegas Daniel Ronda. ${ }^{53}$ Sebab integritas dan keteladan sangat dibutuhkan bagi generasi z dalam membangun komunitas yang tangguh di era disrupsi ini. Karena itu guru sekolah minggu harus mampu memimpin generasi Z kepada tujuan gereja yakni mendewasakan umat Allah agar mereka dapat melayani Allah dan sesama lewat pembinaan yang membangun. Sehingga menghasilkan generasi $\mathrm{Z}$ yang memahami akan kebenaran. Jika peran guru sekolah minggu telah melakukan tindakan yang tepat maka generasi $\mathrm{Z}$ akan hidup dalam kebenaran dan kekudusan. ${ }^{54}$

\section{Kesimpulan}

Hadirnya peran kepemimpinan guru sekolah minggu sebagai pengajar dan pembimbing bagi generasi $\mathrm{Z}$ adalah jawaban dari masalah perkembangan teknologi digital yang tengah merambat kedalam kehidupan generasi Z. Di era disrupsi yang adalah suatu perubahan sistem atau tatanan kehidupan manusia, di mana perubahan yang di maksudkan ialah merujuk pada perkembangan digitalisasi yang begitu cepat sehingga mengubah sebagian besar sistem kehidupan manusia khususnya bagi generasi Z. Perkembangan digital pada awalnya membawa dampak yang baik terhadap sebagian besar aspek kehidupan manusia, khususnya generasi $\mathrm{Z}$ dimana teknologi digital memudahkan berbagai proses aktivitas seperti: bekerja, membaca, menonton, dan lainlain. Namun ternyata kecanggihan digital membawa dampak negatif bagi generasi $\mathrm{Z}$ seperti kecanduan bermain game online yang bisa saja mempengaruhi pola pikir serta kepribadian generasi $\mathrm{Z}$.

Oleh karena itu peran kepemimpinan guru sekolah minggu sangat penting karena berhubungan dengan pertumbuhan spiritualitas generasi Z. peran kepemimpinan guru sekolah minggu yang dimaksudkan ialah memberikan sikap keteladanan yang baik bagi

\footnotetext{
${ }^{51}$ Ibid.

${ }^{52}$ Daniel Ronda, Orasi Ilmiah: Peran Pemimpin Kristen Memasuki Perubahan di Era Disrupsi Teknologi (Makassar: Jaffray, 2018), 13.

53 Ibid.

54 Hariyanto Eko dan Setya Mustafa Pinton, Pengajaran Remedial dalam Pendidikan Jasmani (Banjarmasin: Lambung Mangkurat University Press, 2020), 39-44.
} 
generasi Z agar mereka meneladani sikap itu lalu memberikan dorongan motivasi, didikan, pengajaran dan bimbingan untuk melihat era disrupsi sebagai anugerah Tuhan yang digunakan dalam suatu kebenaran dalam bertindak sehingga integritas generasi $\mathrm{Z}$ dalam membangun komunitas yang tangguh dan berkarakter kristiani agar mereka mampu memuliakan Allah dan melayani Allah.

\section{Referensi}

Femy, Tandilintin Aussie. Anak dan Kecanduan Digital. Jurnal STAKN Toraja, 2018.

Femy, Tandilintin Aussie. Remaja dan Media Sosial. Jurnal STAKN Toraja, 2019.

Fiah, El Rida. Mengembangkan Potensi Kecerdasan Spiritualitas Anak di Usia Dini dan Implikasi Bimbingannya. Jurnal Bimbingan Dan Konseling, 2014.

Hariyanto, Eko dan Pinton Setya Mustafa. Pengajaran Remedial dalam Pendidikan Jasmani. Banjarmasin: Lambung Mangkurat University Press, 2020.

Ika. Era Disrupsi Dan Implikasinya Bagi Reposisi Makna Dan Praktek Pendidikan. Jurnal Media Komunikasi Pendidikan Pancasila dan Kewarganegaraan, 2019.

Karo-karo, Selamat dan Dahlia Panjaitan. Hubungan Keteladanan Guru PAK dengan

Pertumbuhan Spiritual Siswa. Jurnal Pendidikan Religious Vol 2 No 1 (Medan: 2020).

Mardalis. Metode Penelitian: Suatu Pendekatan Proposal. Jakarta: Bumi Aksara, 2010.

Midayana, Evia Darmawani, Dessi Andriani. Dampak Penggunaan Gadget Pada Anak Usia Dini. Jurnal PAUD Vol 2 No 2 (Palembang: 2019).

Nelson, Alan E. Spirituality \& Leadership. Bandung: Kalam Hidup, 2007.

Neolaka, Amos dan Grace Amelia A. Neolaka. Landasan Pendidikan: Dasar Pengenalan diri Sendiri Menuju Perubahan Hidup. Depok: KENCANA,2017.

Nurhayati, Tati. Hubungan Kepemimpinan Transformasional Dan Motivasi Kerja. Jurnal Edueksos, 2012.

Ohoitimur, Johanis. Disrupsi: Tantangan Bagi Perkembangan Ilmu Pengetahuan dan Peluang bagi Lembaga Pendidikan Tinggi. Jurnal Unika Atma Jaya (Jakarta: 2018).

Pandensolang, Flerendo dkk. Peran Guru Sekolah Minggu Terhadap Perkembangan Iman Anak-anak di Jemaat GPIBT “Elim” Tolitoli, Sulawesi Tengah. Jurnal Sekolah Tinggi Agama Kristen Manado.

Pr, Y. Gunawan. Kepemimpinan Kristiani: Melayani Sepenuh Hati. Yogyakarta: Kanisius,2014.

Rahayu, Iman Susanto. Era Dsirupsi: Peluang dan Tantangan Pendidikan Tinggi Indonesia. Jakarta: Akademi Ilmu Pengetahuan Indonesia, 2017.

Ronda, Daniel. Orasi Ilmiah: Peran Pemimpin Kristen Memasuki Perubahan di Era Disrupsi Teknologi. Makassar: Jaffray, 2018.

Sihotang, Kasdim. Berpikir Kritis Kecakapan Hidup Di Era Digital. Yogyakarta: Kanisius, 2019. 
Simanjuntak, Julianto dkk. Merekayasa Lingkungan Anak. Bandung: Kalam Hidup, 2014. Siswanto, Igrea. Digital Multimedia: Teknologi Penunjang Pembelajaran PAK Dan Sekolah Minggu. Tangerang: Matana Publishing, 2016.

Septiadhi, Dwinanda. Disrupsi. Depok: Baraqa Publishing, 2019.

Tanuadjaja, Rahmiati. Spiritualitas Kristen dan Apologetika Kristen. Malang: Literatur Saat, 2018.

Uli, Nadapdap Marta. Pengaruh Profesionalisme Guru Sekolah Minggu Terhadap Pemahaman Materi Yang Diajarkan Pada Anak Usia 9-12 (Kelas Besar) Tahun Di GBI Taman. Jurnal Pendidikan Agama Kristen Regula Fidei Vol 1 No 2, 2016.

Wijoyo, Hadion dkk. Generasi $Z$ dan Industri 4.0. Purwokerto: Pena Persada, 2020. 